\title{
Pineoblastoma in a child with 22q11.2 deletion syndrome
}

\author{
Linda Nguyen, ${ }^{1}$ John Ross Crawford ${ }^{2}$
}

'Department of Neurosciences, University of California San Diego, San Diego, California, USA

${ }^{2}$ Department of Neurosciences and Pediatrics, University of California San Diego, San Diego, California, USA

Correspondence to Dr John Ross Crawford, jrcrawford@ucsd.edu

Accepted 26 August 2018

\section{DESCRIPTION}

A 4-year-old girl with a history of chromosome $22 \mathrm{q} 11.2$ deletion syndrome presented to the emergency department with 2-3 weeks of worsening emesis. CT of the head revealed a large pineal region calcified tumour with associated hydrocephalus. Contrast-enhanced MRI of the brain and spine status postexternal ventricular drain placement confirmed a pineal tumour with diffuse metastatic leptomeningeal spinal spread (figure 1A,B). The child had a normal MRI of the brain 2 years prior (figure $1 \mathrm{C}$ ) as work-up for her developmental delay. The diagnosis of 22q11.2 deletion syndrome was made by chromosomal microarray testing, which revealed a $2.5 \mathrm{MB}$ deletion of $22 \mathrm{q} 11.2$ that included the TBX1 gene. Neuropathology on a subtotal resection showed clusters and sheets of tightly packed, small, blue cells with oval or slightly angulated nuclei and scant cytoplasm, consistent with a primitive neuroectodermal tumour. The tumour showed no loss of expression of INI that would be characteristic of atypical teratoid rhabdoid tumour. In the pineal region, the constellation of neuropathic features is diagnostic of a pineoblastoma. Next-generation sequencing assay of the tumour revealed no reportable genomic alterations. Specifically, there were no reported deletions, duplications or mutations in SMARCB1. Variants of unknown significance of five genes were reported (AR, ARID1B, CARD11, FH and FLT1). The patient was treated with high-dose craniospinal radiation and adjuvant chemotherapy; however, she died of progressive disease 1 year post-therapy.

$22 \mathrm{q} 11.2$ deletion syndrome is the most common microdeletion syndrome, occurring in approximately 1 per 4000 births. It involves variable-sized heterozygous deletions of regions of $22 \mathrm{q} 11$, resulting in a wide phenotypic spectrum that can include cardiac and palatal malformations, immune deficiency, endocrine, genitourinary and gastrointestinal problems, and neuropsychiatric disorders. Although still relatively rare, there are accumulating reports of malignancy in this patient population..$^{12}$ Several reasons have been proposed for their increased risk of malignancy. ${ }^{12}$ These include thymic hypoplasia leading to a range of T-cell defects, and immune deficiency which predisposes to haematological malignancy due to aberrant immune surveillance; an increased frequency and/or severity of infections with possible involvement of carcinogenic viruses such as Epstein-Barr virus; repeated infections creating a state of chronic inflammation, which predisposes to malignancy; and the deletion generally involving the catechol-O-methyltransferase gene, which plays a role in detoxification of certain environmental carcinogens.

It is likely that $22 \mathrm{q} 11.2$ deletion syndrome is the key driver for the development of pineoblastoma in this patient. Pineoblastoma is an exceedingly rare malignant tumour, with an estimated incidence of $<0.1 \%$ of all intracranial tumours. ${ }^{3}$ It typically presents with mass effect and obstructive hydrocephalus, and are rapidly growing and invasive. Known genetic alterations that predispose to pineoblastoma include germline mutations in $R B 1$ and DICER $1 .^{3}$ Treatment consists of surgery, radiotherapy and chemotherapy. This is the second case of pineoblastoma associated with $22 \mathrm{q} 11.2$ deletion syndrome $^{2}$ and the first case with a normal prior MRI.

Further studies are needed to determine the precise incidence and prevalence of malignancy
Check for updates

(c) BMJ Publishing Group Limited 2018. No commercial re-use. See rights and permissions. Published by BMJ.

\footnotetext{
To cite: Nguyen $\mathrm{L}$, Crawford JR. BMJ Case Rep Published Online First: [please include Day Month Year]. doi:10.1136/bcr-2018 226434
}

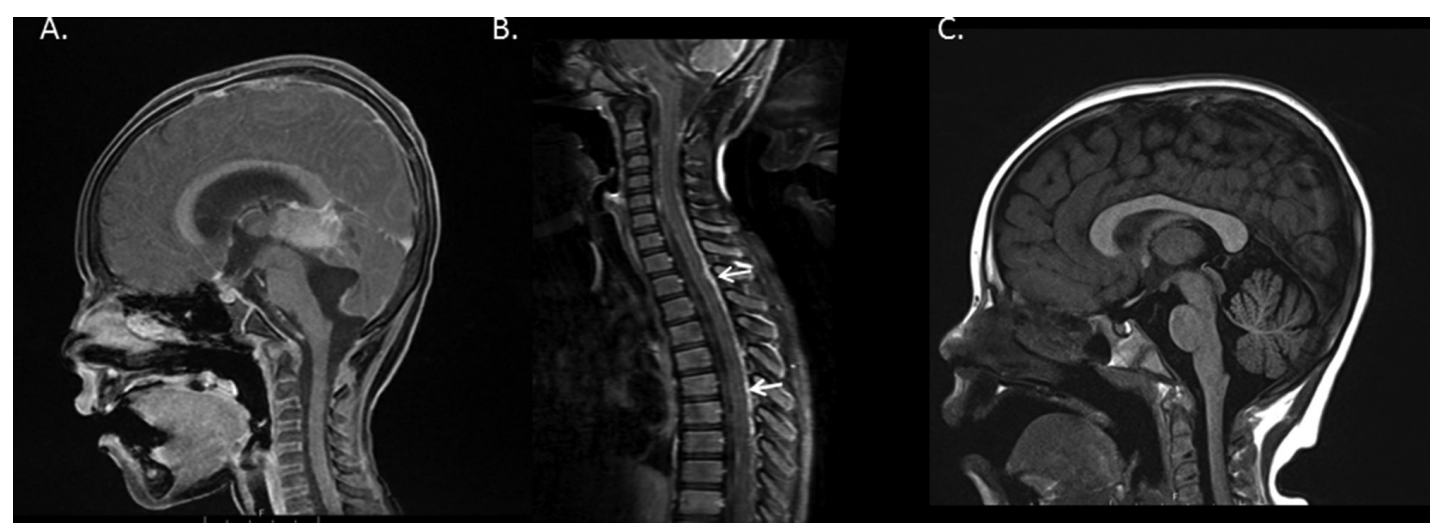

Figure $1 \mathrm{MRI}$ of the brain and spine at presentation ( $A$ and $B$ ) shows a $3.2 \mathrm{~mm}$ pineal mass on $\mathrm{T} 1$ sagittal postcontrast $(A)$ with diffuse leptomeningeal spinal spread ( $B$, arrows). MRI of the brain 2 years prior was normal (C). 


\section{Learning points}

22q11.2 deletion syndrome may be associated with an increased risk of malignancy, including brain cancer.

- Brain tumours should be considered in the differential diagnosis when children with 22q11.2 deletion syndrome present with new-onset neurological signs/symptoms. in association with 22q11.2 deletion syndrome and identify the mechanism by which this patient population may have an increased risk of malignancy. Our case highlights the importance of neuroimaging in patients with 22q11.2 deletion syndrome and illustrates the rapid growth velocity of the disease given the history of a normal MRI 2 years prior to diagnosis.
Contributors Both authors contributed equally to the manuscript and approve of its content. LN and JRC were responsible for the design, analysis and writing of the manuscript.

Funding The authors have not declared a specific grant for this research from any funding agency in the public, commercial or not-for-profit sectors.

Competing interests None declared.

Patient consent Parental/guardian consent obtained.

Provenance and peer review Not commissioned; externally peer reviewed.

\section{REFERENCES}

1 McDonald-McGinn DM, Reilly A, Wallgren-Pettersson C, et al. Malignancy in chromosome 22q11.2 deletion syndrome (DiGeorge syndrome/velocardiofacia syndrome). Am J Med Genet A 2006;140:906-9.

2 Stevens T, van der Werff Ten Bosch J, De Rademaeker M, et al. Risk of malignancy in 22q11.2 deletion syndrome. Clin Case Rep 2017;5:486-90.

3 de Kock L, Sabbaghian N, Druker H, et al. Germ-line and somatic DICER1 mutations in pineoblastoma. Acta Neuropathol 2014;128:583-95.

Copyright 2018 BMJ Publishing Group. All rights reserved. For permission to reuse any of this content visit

http://group.bmj.com/group/rights-licensing/permissions.

BMJ Case Report Fellows may re-use this article for personal use and teaching without any further permission.

Become a Fellow of BMJ Case Reports today and you can:

- Submit as many cases as you like

- Enjoy fast sympathetic peer review and rapid publication of accepted articles

- Access all the published articles

Re-use any of the published material for personal use and teaching without further permission

For information on Institutional Fellowships contact consortiasales@bmjgroup.com

Visit casereports.bmj.com for more articles like this and to become a Fellow 